\title{
PATIENT SATISFACTION REGARDING COMPOUNDED PHARMACEUTICAL PRODUCTS AND IMPLICATIONS ON PHARMACEUTICAL PRACTICE MANAGEMENT
}

\author{
MAGDALENA BÎRSAN ${ }^{1}$, MARIA DRĂGAN ${ }^{1}$, CĂTĂLINA DANIELA STAN ${ }^{1 *}$, ANA CATERINA \\ CRISTOFOR $^{2}$, MATEI PALIMARICIUC ${ }^{2}$, CRISTINEL IONEL STAN ${ }^{3}$, ȘADIYE-IOANA \\ SCRIPCARIU $^{4}$, PAULA ANTONOAEA ${ }^{5}$, ROBERT ALEXANDRU VLAD $^{5}$, ADRIANA CIURBA $^{5}$ \\ I "Grigore T. Popa" University of Medicine and Pharmacy from Iaşi, Faculty of Pharmacy, Department of Drug Industry \\ and Pharmaceutical Biotechnology, 16 Universitătii Street, 700115, Iași, Romania \\ 2 "Grigore T. Popa" University of Medicine and Pharmacy from Iaşi, Faculty of Medicine, Medical Department III, 16 \\ Universitătii Street, 700115, Iaşi, Romania \\ 3 "Grigore T. Popa" University of Medicine and Pharmacy from Iaşi, Faculty of Medicine, Morphofunctional Department I, \\ 16 Universitătii Street, 700115, Iaşi, Romania \\ 4 "Grigore T. Popa" University of Medicine and Pharmacy from Iaşi, Faculty of Medicine, Mother and Child Health \\ Department, 16 Universităţii Street, 700115, Iaşi, Romania \\ 5 "George Emil Palade" University of Medicine, Pharmacy, Science and Technology of Târgu Mureş, Faculty of Pharmacy, \\ Department of Pharmaceutical Technology and Cosmetology, 38 Gheorghe Marinescu Street, 540142, Târgu Mureş, Romania
}

*corresponding author: catalina.stan@umfiasi.ro

\begin{abstract}
Nowadays, industrial pharmaceutical products (IPP) have the largest share in the pharmaceutical market compared to the compounded pharmaceutical products (CPP) for which there are no similitude in the industry. We set out to study the patient satisfaction concerning CPP, as part of the pharmaceutical care received in community pharmacies, using a specific questionnaire. For 4 weeks 1000 questionnaires were completed by patients in a total of 10 community pharmacies from Iaşi County, Romania. The evaluation of patient satisfaction regarding pharmaceutical preparations could be assessed from the perspective of the trust degree in pharmacist advice who recommends these types of pharmaceutical products: CPP or IPP. Patients' responses showed a greater confidence in pharmacist advice regarding the compounded pharmaceutical products made through the pharmaceutical science and art versus their experiences with the industrial pharmaceutical products.
\end{abstract}

\section{Rezumat}

În prezent, preparatele farmaceutice industriale (IPP) au ponderea cea mai mare pe piața farmaceutică comparativ cu preparatele farmaceutice magistrale (CPP), produse pentru care nu există un similar în industrie. Studiul și-a propus evaluarea satisfacției pacienților cu privire la preparatele magistrale (CPP), ca parte a consilierii farmaceutice primite în farmaciile comunitare, utilizând un chestionar. Timp de 4 săptămâni au fost completate 1000 de chestionare de către pacienți, în 10 farmacii comunitare din județul Iași. Evaluarea satisfacției pacienților cu privire la preparatele farmaceutice poate fi făcută din perspectiva gradului de încredere în farmacistul care recomandă produsele farmaceutice, magistrale sau industriale. Răspunsurile pacienților au arătat o mai mare încredere în recomandările și consilierea cu privire la produsele farmaceutice realizate în farmacie, recurgând la știința și arta preparării acestora, față de propriile lor experiențe referitoare la produsele farmaceutice industriale.

Keywords: patient satisfaction, compounded pharmaceutical products, patient decision-making process, pharmaceutical care

\section{Introduction}

Due to the fulminant development of the major pharmaceutical companies and the current trend of industrialization in all fields, CPP (compounded pharmaceutical products) have drastically decreased both in recommendations and in use [1].

The current trend is to shorten the time spent with the patient by both the physicians and the pharmacists [2]. The number of physicians that prescribe CPP is extremely low and, because of the current market, there are many other convenient treatment options to use $[3,4]$. The few diseases that can be treated using CPP are likely to no longer have this option in the near future. However, in these times, in the United States compounded prescriptions comprises up to $3 \%$ of the prescription market [5].

A brief explanation for the decrease in CPP recommendation is that there is no longer an obligation for the pharmacy to honour any prescriptions and virtually community pharmacies may operate without a compounding room, according to current normative [6-13]. 
Nowadays, industrial pharmaceutical products (IPP) have the largest share in the pharmaceutical market, about $98 \%$. Many patients will have to resort to IPP (mainly patients with oral mucosal diseases, dermatological and gynaecological ailments), unless pharmacists agree to compound pharmaceutical products.

This issue will be reflected not only on patients, but also on pharmacists and pharmacies, as fewer pharmacies are equipped with a compounding room, and fewer pharmacy graduates have the opportunity to learn how to formulate and compound these pharmaceutical products $[14,15]$.

On the other hand, throughout the world, the pharmacy profession involves activities such as compounding, preparing and manufacturing medicines. All these activities increase patient access to medicines and are based on proper procedures which guarantee the quality and safety of preparations by pharmacists [9]. Compounding is essential for paediatric and elderly patients, offering for these special patients ageadapted drug formulations. It also completes the lack of treatment options for certain patients with extraordinary medical needs (i.e. oncologic patients) and adaptation to an extraordinary situations like pandemics or medicines shortages [16].

Improving pharmaceutical services is a constant concern for pharmacists, with the focus on increasing patient satisfaction $[17,18]$. Patient satisfaction can be measured by surveys, where expressed satisfaction

is valid and reliable if it is used on a large scale [1924]. Health care specialists are aware that providing CPP in community pharmacies has significant benefits to patients.

Our study wants to evaluate, based on a specific questionnaire, answers of 1,000 patients from Iaşi County, Romania, the patient satisfaction regarding the CPP. The questionnaire was developed to gather information about frequency, type and credibility of CPP.

\section{Materials and Methods}

A cross-sectional study was carried out in Iaşi County, Romania, in 10 selected community pharmacies on the basis of an anonymous distributed questionnaire to patients who agreed to answer the proposed questionnaire. The questionnaire design was based on previous literature studies [25-27].

The questionnaire was brief and included seven easyto-understand and easy-to-answer questions for adults (Table I). Patients have been asked to answer it after the pharmaceutical act was provided, and to place the questionnaire into a marked box on departure. Patients under the age of 18 were excluded. 1,000 completed questionnaires were selected. Practically, every question had at least one answer. The large number of questionnaires proposed in the study has been established in order to draw some relevant conclusions.

Table I

The proposed questionnaire

\begin{tabular}{|c|c|}
\hline Question & Answer \\
\hline \multirow{3}{*}{$\begin{array}{l}\text { 1. How often do you buy pharmaceutical products or dietary supplements } \\
\text { from a pharmacy? }\end{array}$} & Monthly \\
\hline & Weekly \\
\hline & Annual \\
\hline \multirow{2}{*}{$\begin{array}{l}\text { 2. Do you know the differences between compounded pharmaceutical } \\
\text { products (CPP) and industrial pharmaceutical products (IPP)? }\end{array}$} & Yes \\
\hline & No \\
\hline \multirow{6}{*}{ 3. Have you ever used a CPP? } & Was it recommended by a pharmacist? \\
\hline & Was it prescribed by a physician? \\
\hline & Yes Was it a friend's recommendation? \\
\hline & Was it your request? \\
\hline & No \\
\hline & I don't know \\
\hline \multirow{3}{*}{ 4. Do you consider that CPP you have used was effective? } & Yes \\
\hline & No \\
\hline & I don't know \\
\hline \multirow{2}{*}{ 5. Do you rely on pharmacists' opinion? } & Yes \\
\hline & No \\
\hline \multirow{2}{*}{ 6. Do you consider that the supply for CPP should be higher? } & Yes \\
\hline & No \\
\hline \multirow{3}{*}{ 7. If there were both CPP and IPP for your illness, which would you choose? } & Compounded \\
\hline & Industrial \\
\hline & I don't know \\
\hline
\end{tabular}

The questionnaire was piloted on 1,000 patients for clarity, relevance, acceptability and time to completion. Data collection took place over a 4-week period during normal day working hours in a total of 10 community pharmacies from Iaşi County, Romania, 8 out of 10 pharmacies involved in the project having a compounding room and were well-known to provide pharmaceutical service of producing CPP. Pharmacies were selected 
according to the possibility of obtaining the consent of the pharmacy manager and the availability of pharmacists to provide the questionnaire to patients. For one month all patients who entered the pharmacies involved in the study were asked to complete the questionnaire. After giving their consent, the patients received the questionnaire, without any time limit being imposed. Usually, the patients completed the questionnaire in 2 - 10 minutes. Each pharmacy had above of 100 questionnaires to distribute and return the first 100 of them completed after one month. Only pharmacists were involved in the implementation of this study, with no access to pharmaceutic assistants. If patients had questions about the questionnaire, the pharmacists answered them without indicating any answer to participants. After checking the questionnaire's validity, the pharmacist assured sure that the patient understood the topic of the study.

All questionnaires were analysed regardless on their completeness. The questionnaire is reliable under the terms of the study and may be used for research, pharmaceutical/medical education and auditing purposes. The research was carried out in accordance with the principles of pharmaceutical practice regulated in Romania and with the Declaration of Helsinki (1975), as revised in 2000 [28].

Statistical analysis

The results were analysed using the Statistical Package for Social Sciences (SPSS) version 19.0 for Windows. Frequency and percentage statistics were represented in the obtained results. The non-parametric Pearson

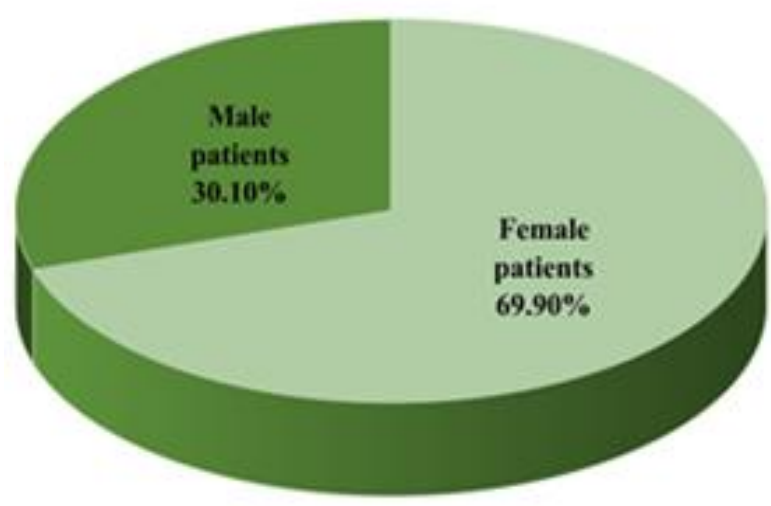

Correlation was used for comparison of the answers of 2 questions. For all the statistical analyses the significant level of $\mathrm{p}<0.05$ was set.

\section{Results and Discussion}

The analysis of the main components of the evaluations of CPP revealed three satisfaction factors: awareness regarding CPP, their use and the frequency of treatments. The cumulative patient experience was comprised in the answers of a seven-question questionnaire with a multi-point response scale.

Patients filled in the questionnaire when leaving the pharmacy, usually after taking their prescription or after purchasing an over the counter medicine (OTC). The name and surname were not entered on the questionnaire, leaving the possibility of anonymity available. Instead, the age and sex category had to be checked and the questions were usually with a single answer. One thousand patients have filled out the questionnaire and each patient were assigned to an age group (Figure 1). Patients who completed the questionnaire were predominantly women $(69.90 \%)$ : $20.1 \%$ between 18 - 34 years, $29.7 \%$ between 35 54 years and $20.1 \%$ after 55 years. The men who completed the questionnaire were: $4.9 \%$ between 18 34 years, $9.0 \%$ between 35 - 54 years and $16.2 \%$ after 55 years. The higher number of women who answered this study can be explained by their greater interest in health than men [29].

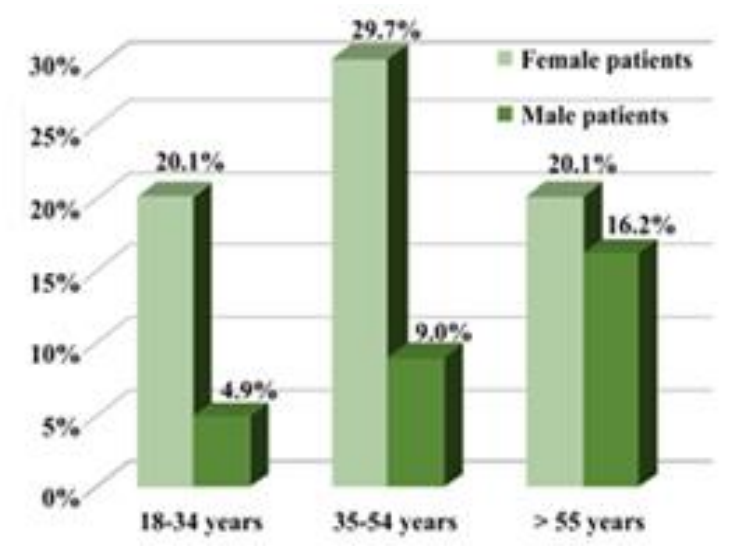

Figure 1.

Response rate by age and gender

It is recognized that women are more interested in health than men, the age of people who attend certain community pharmacies cannot be generalized because it can be an issue related to the marketing of that pharmacy. For the 10 pharmacies that entered this study, the highest percentage of patients $(29.7 \%)$ were women between 35 - 54 years old. Practically the high ratio of patients in this category can be explained by the affinity of women to health for both them and their family.
The frequency of patients in the community pharmacy depends on external factors such as the visibility of the location, the availability of existing products, the quality of pharmaceutical counselling, etc. Over $50 \%$ of all patients that have filled out the questionnaire responded that the frequency of going to the pharmacy for prescriptions, for OTC or for dietary supplements was monthly (Figure 2). 


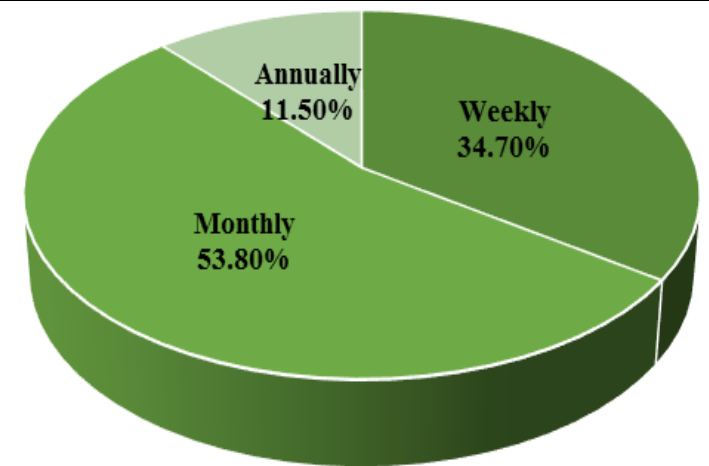

Figure 2.

Purchase frequency for pharmaceutical products or dietary supplements from a pharmacy

\section{Do you know the differences between CPP and IPP?}

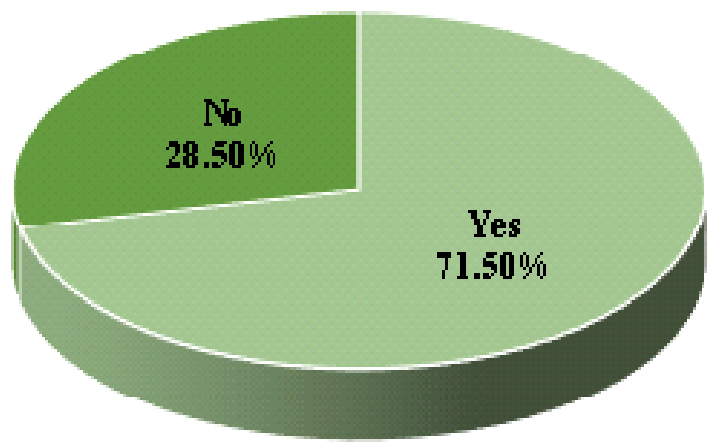

Taking into account that patients with chronic illness go to their family doctor monthly to receive prescriptions, explained the obtained results. The percentage of patients that resort to pharmaceutical services weekly was $34.7 \%$ and it reflects the level of education of the population. The more the patients rely on the physician and pharmacist, the faster and more efficient the prevention process is.

Although, less than $20 \%$ of the community pharmacies have a compounding room, $71.5 \%$ of the patients who responded had knowledge of CPP and $68.1 \%$ of them had used at least once in a lifetime a CPP (Figure 3).

Figure 3.

Percentage of patients that are aware and have used CPP

The frequency of CPP use was closely related to the recommendation of a physician or pharmacist since patients who have used at least once in their lifetime such pharmaceutical products responded that $45 \%$ had a prescription and $26 \%$ decided to use a CPP based on the pharmacist recommendation. Only $19 \%$ answered that it was their choice to use such a preparation (Figure 4).

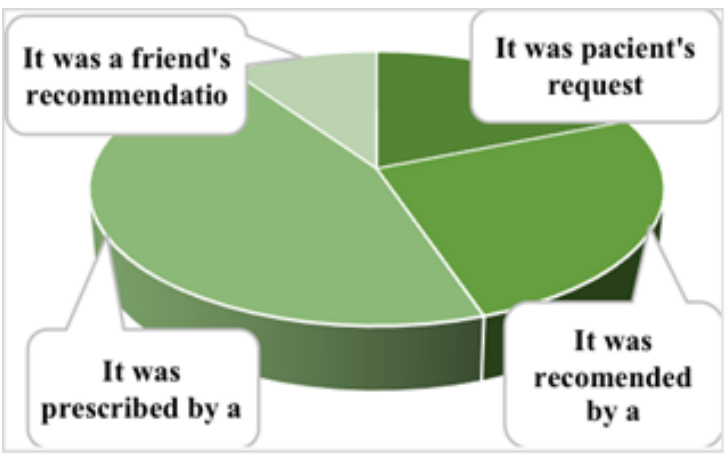

Figure 4.

Motivation for choosing CPP

The $63 \%$ success rate confirms that CPP could be used in a disease treatment just well as IPP, especially since each person responds differently to the treatment (Figure 5). These results are sustained by the literature, many published papers estimating that in the future CPP may be used more often than the industrial products [30-33]. Furthermore, it is possible that there is a certain psychological advantage in favour of CPP, as patients perceive its personalized quality.

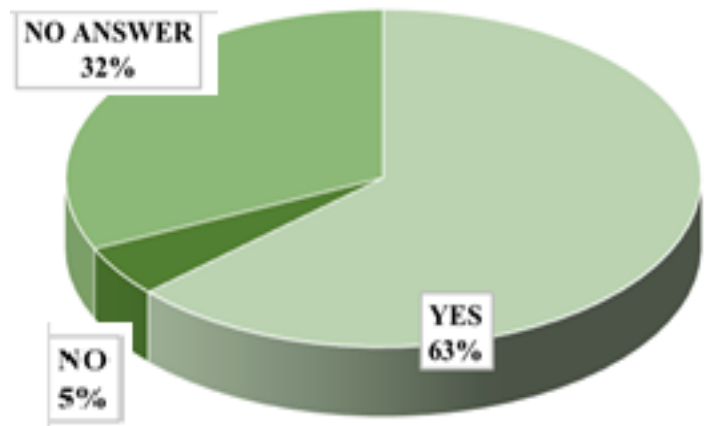

Figure 5.

Success rate of treatment using CPP

In these days pharmacists stands out as a health professionals who are the only one specialized in the area of drugs $[34,35]$. This statement is underlined 
by the results obtained in this study, $82.1 \%$ of patients answered that they rely on pharmacist opinion, proving a great credibility of patients in the pharmacist advice (Figure 6).

\section{Do you rely on pharmacist's opinion?}

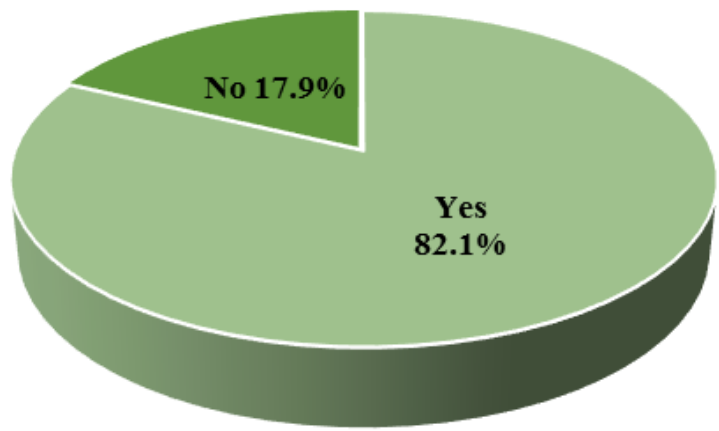

Figure 6.

Pharmacists`́ credibility

Moreover, $64.5 \%$ of the patients said they would choose a CPP in favour of the equivalent IPP (Figure 7 ), and $74 \%$ do believe that the requirement is higher than the supply (Figure 8).

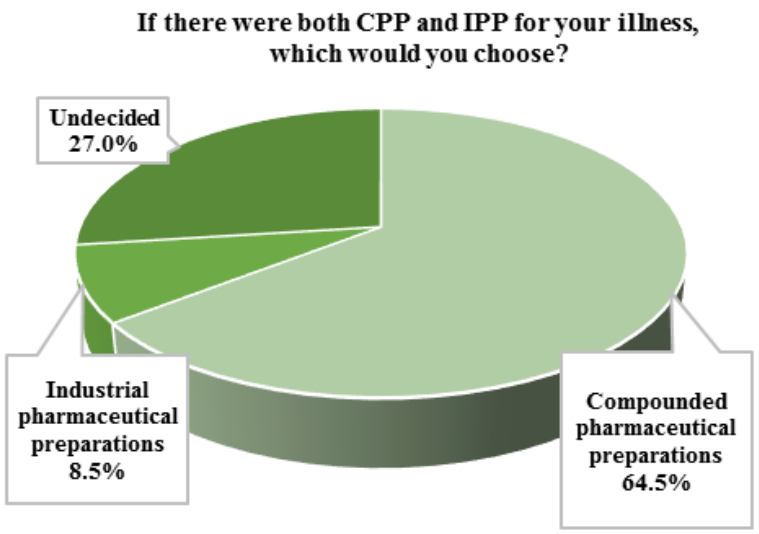

Figure 7.

Patient's choice regarding CPP

\section{Do you agree that the need for CPP is higher than the supply?}

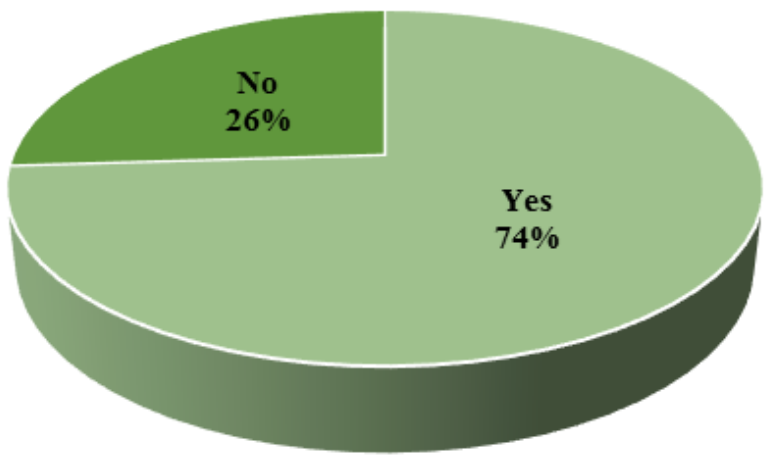

Figure 8.

Patient's perception regarding CPP requirement
The significant positive correlation $(r=0.682 ; \mathrm{p}=0.01)$ proved the importance of CPP, that was directly proportional to patient confidence in pharmacists. This correlation showed that patients who trust their pharmacist are more likely to use CPP and, on the other hand, the ability to prepare CPP could serve as a marker of confidence in pharmacists from patient's perspective. This correlation can help to surpass many of the current milestones in the pharmaceutical field and could lead to a better relationship in the physicianpatient-pharmacist triangle.

Data from literature shows that patients' satisfaction with their treatments was linked with a higher success rate of treatment [36-46]. Our results highlight that patients who trust their pharmacist are more likely to evaluate their treatment efficiency. Regardless of the correlation $(r=0.511, p=0.01)$ or patients' trust in pharmacists, as a result of providing quality pharmaceutical services including CPP, the benefits are in the end in patients' favour. Also, the intensity of the correlation between items 2 and 6 is significant $(r=0.921, p<0.05)$. Promoting CPP could be highly beneficial for pharmacies and this might reflect in patients' satisfaction with both their treatments and their pharmacist. Patients' satisfaction with treatment using CPP led to the first choice of such a preparation versus the industrial preparation. Significantly positive correlation $(r=0.72, p<0.05)$ confirms that option for the patients.

The positive correlation of items 5 and 7 provides the "key" of the pharmaceutical act through the intensity of the relationship between the pharmacist's position, his recommendations and the choice of pharmaceutical preparation selected by the patient. The relationship between the two items was highly significant $(r=0.727, p=0.01)$, which allows us to express that pharmacists with experience in the art and science of mixing compounded products enjoy higher levels of trust from their patients. We can also state that the services provided by the pharmacists are in high demand, being in contrast with current opinion that CPP account for less than $2 \%$ of the market.

The study had several limitations. Despite the large set of results we consider this questionnaire a clamping point for a future larger study that could target a greater number of pharmacies. Pharmaceutical counselling is closely related to patient's trust in the pharmacist, which is why we consider it a point of reference for a broader vision of understanding the patient's psychology in choosing a pharmacy or a pharmacist. Another limitation can be seen in the results themselves which are correlated with the type of pharmacies included in the study, with or without a compounding room.

\section{Conclusions}

Even if the century of speed and massive industrialization in which we live leads us to minimize the pharmaceutical 
act and to diminish the use of CPP, the proposed questionnaire revealed the patient's opinion on the issue. Patients clearly have a favourable opinion for $\mathrm{CPP}$, and the market should reflect on this opinion, taking into account that not only the patient has benefits, but also the pharmacists. This cross-sectional study can be beneficial to pharmacists/pharmacies in order to achieve an efficient management and for enhancing the quality of patient-oriented pharmaceutical care services.

\section{Conflict of interest}

The authors declare no conflict of interest.

\section{References}

1. Schellekens H, Aldosari M, Talsma H, Mastrobattista E, Making individualized drugs a reality. Nat Biotechnol., 2017; 35(6): 507-513.

2. Selmin F, Casiraghi A, Minghetti P, Purchasing for Safety. In: Resolution and Pharmacy Compounding. Hospital Pharmacy Europe Suppl., Council of Europe, 2016; 6-9.

3. Lutz E, Pauletti G, Carvalho M, Davidson G, Ashworth L, Subramaniam V, Llambí F, The role of compounding in closing therapeutic gaps-abstracts from FIP 2013: when not to compound and considerations before compounding. Int J Pharm Compd., 2014; 18(1): 8-9.

4. Roy S, Descamps F, Planas V, Caudron E, Husson MC, Do B, Cysteamine eyedrops: optimisation of the manufacturing process and meeting safety and efficacy criteria for continuous supply. Int J Clin Pharm., 2011; 33(2): 378-379.

5. Pignato A, Birnie CR, Analysis of Compounded Pharmaceutical Products to Teach the Importance of Quality in an Applied Pharmaceutics Laboratory Course. Am J Pharm Educ., 2014; 78(3): 1-8.

6. McPherson TB, Fontane PE, Day JR, Patient-centered care as value-added service by compounding pharmacists. Int J Pharm Compd., 2013; 17(4): 339-343.

7. Palmeira-de-Oliveira R, Macedo M, Machado RM, Pacheco AF, Palmeira-de-Oliveira A, Martinez-deOliveira J, Duarte P, Pharmaceutical Compounding in Portuguese Community Pharmacies: Characterization and future perspectives. Int J Pharm Compd., 2016; 20(2): 114-122.

8. Zaid AN, Al-Ramahi R, Shahed Q, Saleh B, Elaraj $\mathrm{J}$, Determinants and frequency of pharmaceutical compounding in pharmacy practice in Palestine. Int $J$ Pharm Pract., 2012; 20(1): 9-14.

9. *** Resolution CM/ResAP (2016) 1 on quality and safety assurance requirements for medicinal products prepared in pharmacies for the special needs of patients. Council of the EU, 2016; 1-9.

10. $* * *$ The rules governing medicinal products in the European Union: EU guidelines for good manufacturing practice for medicinal products for human and veterinary use. European Commission. Eudralex, 2016; 4: 1-25.

11. $* * *$ Directive 2001/83/EC of 6 November on the community code relating to medicinal products for human use. European Parliament and the Council. Official Journal of the European Communities, 2001; L311: 67-128.
12. *** Directive 2004/27/EC of 31 march amending directive 2001/83/EC on the community code relating to medicinal products for human use. European Parliament and the Council. Official Journal of the European Union, 2004; L136: 34-57.

13. *** Guide to good practices for the preparation of medicinal products in healthcare establishments. PE 010-4. Pharmaceutical Inspection Cooperation Scheme, 2014; $1-9$.

14. Lobb WB, Wilkin NE, Holmes ER, Pharmacists' Perceptions of the Economic Value of Compounded Pharmaceuticals: A Comparison of Compounded and Commercial Pharmaceuticals in Select Disease States. Int J Pharm Compd., 2015; 19(6): 514-520.

15. Rowe RC, Sheskey PJ, Cook WG, Fenton ME, Handbook of pharmaceutical excipients, $7^{\text {th }}$ edition, London Pharmaceutical Press, Royal Pharmaceutical Society, 2012; IX-XIII.

16. Bourika K, Koutras A, Kalofonos H, Vicha A, Tsiata E, Papadimitriou E, Avgoustakis K, Panagi Z, Improvement of Chemotherapy Solutions Production Procedure in a Hospital Central Chemotherapy Preparation Unit: A Systematic Risk Assessment to Prevent Avoidable Harm in Cancer Patients. Clin Med Insights Oncol., 2019; 13: 1179554919852933: 1-10.

17. Nistor G, Urea R, Neacşu I, Youth protection and education today: perceived vulnerabilities, statistical issues, perspectives. Revista de Cercetare şi Intervenţie Socială, 2014; 44: 44-66.

18. Traverso ML, Salamano M, Botta C, Colautti M, Palchik V, Perez B, Questionnaire to assess patient satisfaction with pharmaceutical care in Spanish language. Int J Qual Health Care, 2007; 19(4): 217-224.

19. Atkinson MJ, Kumar R, Cappelleri JC, Hass SL, Hierarchical construct validity of the treatment satisfaction questionnaire for medication (TSQM version II) among outpatient pharmacy consumers. Value Health, 2005; 8(1): S9-S24.

20. Barbosa CD, Balp MM, Kulich K, Germain N, Rofail $\mathrm{D}$, A literature review to explore the link between treatment satisfaction and adherence, compliance, and persistence. Patient Prefer Adherence, 2012; 6: 39-48.

21. Chassany O, Sagnier P, Marquis P, Fullerton S. Aaronson N, Patient reported outcomes: The examples of health-related quality of life - A European guidance document for the improved integration of health-related quality of life assessment in the drug regulatory process. Drug Information J., 2002; 36(1): 209-238.

22. Hale A, Coombes I, Stokes J, Aitken S, Clark F, Nissen L, Patient satisfaction from two studies of collaborative doctor - pharmacist prescribing in Australia. Health Expect., 2016; 19(1): 49-61.

23. Hoti K, Hughes J, Sunderland B, Pharmacy clients' attitudes to expanded pharmacist prescribing and the role of agency theory on involved stakeholders. Int J Pharm Pract., 2011; 19(1): 5-12.

24. Ramez W, Patients' perceptions of health care quality, satisfaction and behavioral intention: an empirical study in Bahrain. Int J Business Social Sci., 2012; 3(18): 131-141.

25. Steward D, George J, Bond C, Cunningham I, Diack $\mathrm{H}$, McCaig D, Exploring patients' perspectives of 
pharmacist supplementary prescribing in Scotland. Pharm World Sci., 2008; 30(6): 892-897.

26. Minarikova D, Molovecka I, Foltan V, Patient choice of pharmacy and satisfaction with pharmaceutical care - Slovak regional comparison. Farmacia, 2016; 64(3): 473-480.

27. Cerbin-Koczoroswka M, Przymuszala P, Michalak M, Piotrowska-Brudnicka SE, Kant P, Skowron A, Comparison of medical and pharmacy students readiness for interprofessional learning-A cross-sectional study. Farmacia, 2020; 68(6): 1166-1172.

28. *** World Medical Association, World Medical Association Declaration of Helsinki: ethical principles for medical research involving human subjects. JAMA., 2013; 310(20): 2191-2194.

29. Manteuffel M, Williams S, Chen W, Verbrugge RR, Pittman DG, Steinkellner A, Influence of patient sex and gender on medication use, adherence, and prescribing alignment with guidelines. $J$ Womens Health (Larchmt), 2014; 23(2): 112-119.

30. Andrei CL, Ciolan DF, Mirică A, Toma IE, Drăgănescu D, Rădulescu FS, Internships and the next generation of pharmacists in Romania. Farmacia, 2019; 67(5): 378-382.

31. Rough SS, McDaniel M, Rinehart JR, Effective use of workload and productivity monitoring tools in health-system pharmacy part 1. Am J Health Syst Pharm., 2010; 67(4): 300-311.

32. Rough SS, McDaniel M, Rinehart JR, Effective use of workload and productivity monitoring tools in health-system pharmacy part 2. Am J Health Syst Pharm., 2010; 67(5): 380-388.

33. Siden R, Tamer HR, Skyles AJ, Pharmacist-prepared dispensing guidelines for drugs used in clinical research. Am J Health Syst Pharm., 2012; 69(12): 1021-1026.

34. Kokane JV, Avhad PS, Role of Pharmacist in Health Care System. J Community Health Management, 2016; 3(1): 37-40.

35. Kim Jun J, The Role of Pharmacy through Collaborative Practice in an Ambulatory Care Clinic. Am J Lifestyle Med., 2019; 13(3): 275-281.

36. Požgain I, Požgain Z, Degmečić D, Placebo and nocebo effect: a mini-review. Psychiatr Danub., 2014; 26(2): 100-107.

37. Chinthrajah RS, Purington N, Andorf S, Long A, O'Laughlin KL, Lyu SC, Manohar M, Boyd SD, Tibshirani R, Maecker H, Plaut M, Mukai K, Tsai M, Desai M, Galli SJ, Nadeau KC, Sustained outcomes in oral immunotherapy for peanut allergy (POISED study): a large, randomised, double-blind, placebocontrolled, phase 2 study. Lancet, 2019; 394(10207): 1437-1449.

38. Nourbakhsh B, Revirajan N, Morris B, Cordano C, Creasman J, Manguinao M, Krysko K, Rutatangwa A, Auvray C, Aljarallah S, Jin C, Mowry E, McCulloch C, Waubant E, Safety and efficacy of amantadine, modafinil, and methylphenidate for fatigue in multiple sclerosis: a randomised, placebo-controlled, crossover, double-blind trial. Lancet Neurol., 2021; 20(1): 38-48.

39. O'Dwyer S, Greene G, MacHale E, Cushen B, Sulaiman I, Boland F, Bosnic-Anticevich S, Mokoka MC, Reilly RB, Taylor T, Ryder SA, Costello RW, Personalized Biofeedback on Inhaler Adherence and Technique by Community Pharmacists: A Cluster Randomized Clinical Trial. J Allergy Clin Immunol Pract., 2020; 8(2): 635-644.

40. Ried LD, Wang F, Young H, Awiphan R, Patients' satisfaction and their perception of the pharmacist. J Am Pharm Assoc (Wash.), 1999; 39(6): 835-842.

41. Bishop L, Young S, Twells L, Dillon C, Hawboldt J, Patients' and physicians' satisfaction with a pharmacist managed anticoagulation program in a family medicine clinic. BMC Res Notes, 2015; 8: 233: 1-7.

42. Goode JV, Upshur R, Grimes MB, Nadpara P, Patient satisfaction with pharmacist-administered Mantoux tuberculin skin test in a community-based pharmacy setting. J Am Pharm Assoc., 2019; 59(4S): S77-S80.

43. Kabba JA, Bah AJ, James PB, Chang J, Kitchen C, Jiang M, Zhao M, Fang Y, Patients satisfaction with free healthcare pharmaceutical services in Sierra Leone: a national cross-sectional study. Int J Clin Pharm., 2021; 43(3): 556-565.

44. Osae SP, Rotelli A, Pharmacist-Led Annual Wellness Visits: A Review. J Pharm Pract., 2021; 34(2): 295-305.

45. Miles A, Ginsburg S, Sibbald M, Tavares W, Watling C, Stroud L, Feedback from health professionals in postgraduate medical education: Influence of interprofessional relationship, identity and power. Med Educ., 2021; 55(4): 518-529.

46. Ruiz-Millo O, Climente-Martí M, Navarro-Sanz JR, Patient and health professional satisfaction with an interdisciplinary patient safety program. Int J Clin Pharm., 2018; 40(3): 635-641. 